\title{
TRAINING OF COCONUT BUSINESS STRATEGIES AS MICRO, SMALL BUSINESS, MEDIUM ENTERPRISES IN MERUYA SELATAN VILLAGE
}

\author{
Aty Herawati \\ Faculty of Economics and Business, Universitas Mercu Buana, Indonesia \\ atyherawati@gmail.com
}

\begin{abstract}
The development of the industrial sector, whether large, medium, small, micro or home industry, is basically an effort to improve the standard of living and welfare of the people. The development of the industrial sector is an activity directed towards developing the industry by increasing added value and can create jobs for the community. The household industry also requires workers both adults and young people who have skills. Workers in the production process can come from the family, the surrounding community or outside the area. Therefore a strategy is needed that can empower sustainable communities. Efforts to mobilize resources to develop the potential of the community by developing an entrepreneurial spirit. One form of entrepreneurship is the processing of coconut which can be done on a home industry scale in the Kembangan District area, especially in the South Meruya Village. This location has a location adjacent to the coconut producing area in Banten Province. This service has the purpose of conducting entrepreneurial training by raising awareness of the potential that is owned, knowing and knowing how to obtain raw materials, carrying out the production process and marketing of processed products. The number of participants invited as many as 30 people consisting of people in various RTs in various villages in South Meruya District. The method of implementing this activity refers to a sustainable coaching program. through several stages of business training, mentoring, handling and business networks. The results of the training evaluation revealed that participants stated that training was very useful to improve understanding regarding the effectiveness of interpersonal communication in coconut management.
\end{abstract}

Keywords: Business strategies, entrepreneurship, interpersonal communication

\section{INTRODUCTION}

Empowerment (economy) is an effort to build creative power by encouraging, motivating, and raising awareness of the potential that is owned and trying to develop by strengthening the potential of the community. Community economy is an economic activity carried out by the community independently by managing any resources that can be controlled and aimed at meeting their basic needs and family needs (Mubyarto, 1996).

The development of the industrial sector, whether large, medium, small, micro or home industry, is basically an effort to improve the standard of living and welfare of the people. The development of the industrial sector is an activity directed towards developing the industry by increasing added value and can create jobs for the community. The household industry also requires workers both adults and young people who have skills. Workers in the production process can come from the family, the surrounding community or outside the area. Therefore a strategy is needed that can empower sustainable communities. A strategy is an effort to mobilize resources to develop the potential of the people that will increase the productivity of the people both human resources and natural resources that are around (Mubyarto, 1996).

Efforts to mobilize resources to develop the potential of the community by developing an entrepreneurial spirit. According to Zimmerer (2010), the profile of entrepreneurs is to like responsibility, like medium risk, have confidence in the ability to achieve success, have a desire to get 
immediate feedback, have high energy, are forward oriented, have higher organizational skills and value achievement than money.

The coconut processing industry can be carried out on a home industry scale in the Ciledug Subdistrict, especially in the Sudimara Timur Village. This location has a location adjacent to the coconut producing area in Banten Province. According to Tarigan (2005), the use of coconut to produce a variety of processed products can be carried out from coconut parts such as fruit meat, coconut water, shells, coir, and flower bunches.

Besides processing coconut, marketing knowledge is also needed. Marketing according to Stanton (2005) is a process of preparing integrated communication that aims to provide information about goods or services in relation to satisfying human needs and desires. In running a small business, there is a need for development through its marketing strategy, because in times of critical conditions it is the only small business that is able to provide growth to people's income. Strategies in marketing communication should be arranged in a logical structure of the planning system of SOSTAG messages (Situation, Objective, Strategy, Tactic, Action, Control) (Prisgunanto, 2006). The things that need to be considered for marketing are quality products (products), competitive prices (prices), a promotion that is promotion and a strategic place (place). Then the selection of marketing locations becomes important.

Another factor that can be used as a force in the processing and marketing of this coconut is the presence of several Posdaya in Kelurahan Meruya Selatan, so that the processing and marketing of this coconut can be the activities of mothers and youth who do not work to increase economic potential and take advantage of creative economic opportunities.

\section{LITERATURE REVIEW}

The term creative economy was first introduced by Howkins (2001) who realized the birth of a new wave of a creativity-based economy after seeing in 1997, the United States produced Intellectual Property Rights (IPR) products worth 414 billion dollars which made IPR the number one export item in the United States of America.

Howkins (2001) defines the creative economy as the creation of value as a result of an idea, namely economic activity in a society that spends most of its time producing ideas, not only doing routine and repetitive things. Because for this community, generating ideas is something that must be done to progress. So, empowering the creative economy is an effort to build by encouraging, motivating and raising awareness of the potential that is independently owned by the community that is done to develop ideas in managing existing resources and aimed at progress.

Based on the concept and application of community empowerment, in essence, empowerment strategies have a direction: (1) community maintenance and empowerment. (2) strengthening autonomy and delegation of authority in development management that develops community participation, and (3) modernization through changes in the socio-economic structure, culture and political structures that originate in community participation. Meanwhile, according to Mubyarto (1996), the development of people's economy can be seen from three sides, namely: first, creating conditions that enable the potential of the community to develop, second, strengthening the economic potential of the community to take advantage of economic opportunities and third, protecting the people and preventing unbalanced competition.

According to Asy'arie (1997), sustainable development programs can be carried out through the following stages:

\section{Phase 1: Business Training}

Training provides an understanding of entrepreneurial concepts, with all kinds of problems in

them. The aim of business training is to provide insight that is more comprehensive and actual, so that it can foster motivation, besides being expected to have theoretical knowledge. Through training, it is expected to be able to observe the existence of certain tips for success, so that it can be avoided as small as possible the failure in developing entrepreneurship.Training will also provide an understanding of marketing concepts. The purpose of this training is to provide more thorough and actual insights on how to provide information about goods by satisfying the needs and desires of consumers while being expected to have theoretical knowledge. Through training, it is expected to be able to develop through 
marketing strategies by paying attention to quality products, competitive prices, vigorous promotions, and strategic places.

Phase 2: Assistance

At this stage, that is when the business starts to run, the prospective entrepreneur will be accompanied by a professional, who functions as a director and as well as a mentor. This assistance is carried out through the process of finding raw materials, the process of production (processing) to marketing. Thus, the business activities they are doing are truly successful and able to be mastered.

Phase 3: Handling

Handling here is the handling carried out by the entrepreneur related to the business he will choose. This handling is very necessary because the atmosphere and reality of the business have different characteristics with the world of education or activities outside of business. Without an introduction to the reality of business intensely and empirically, it will be difficult for someone to start his business.

Phase 4: Business Network

With various stages of coaching that are consistent, systematic and sustainable, the birth of a true entrepreneur is just waiting for time. The next process needs to be established business networks that complement each other, strengthen and expand the market.

\section{METHOD}

The method of implementing this activity refers to the ongoing coaching program through the following stages:

Phase 1: Business Training

Through this training, participants are given an understanding of entrepreneurial concepts, with all kinds of problems in them. The purpose of business training is to provide more comprehensive and actual insights, so as to foster motivation for participants, in addition to the expected participants having theoretical knowledge. Through training like this, participants are expected to be able to observe the existence of certain tips for success, so that it can be avoided as little as possible the failure in developing entrepreneurship. Participants will also be given an understanding of marketing concepts. The purpose of this training is to provide a more thorough and actual insight on how to provide information about goods by satisfying the needs and desires of consumers, in addition to the expected participants having theoretical knowledge. Through training like this, participants are expected to be able to develop through marketing strategies by paying attention to quality products, competitive prices, vigorous promotions, and strategic places.

\section{Phase 2: Assistance}

At this stage, that is when the business starts to run, the prospective entrepreneur will be accompanied by a professional, who functions as a director and as well as a mentor. This assistance is carried out through the process of finding raw materials, the process of production (processing) to marketing. Thus, the business activities they are doing are truly successful and able to be mastered.

\section{Phase 3: Handling}

Handling here is the handling carried out by the entrepreneur related to the business he will choose. This handling is very necessary because the atmosphere and reality of the business have different characteristics with the world of education or activities outside of business. Without an introduction to the reality of business intensely and empirically, it will be difficult for someone to start his business. 
Phase 4: Business Network

With various stages of coaching that are consistent, systematic and sustainable, the birth of a true entrepreneur is just waiting for time. The next process needs to be established business networks that complement each other, strengthen and expand the market.

\section{Target Audience}

The target of the group that received this socialization material was the community of South Meruya Village which was not far from the campus environment of Mercu Buana University. The number of participants invited as many as 30 people consisting of communities in various RTs in various RWs in North Meruya District.

\section{RESULT AND DISCUSSION}

North Meruya District has human resources that can actually be used to further enhance their ability to meet their needs. In other side, there are problems encountered such as there are no thought for entrepreneurship. This is due to lack of knowledge about entrepreneurial concepts, ranging from seeing opportunities, innovative ideas, identifying business types, developing a business, and running a business that is formed in conditions of risk or uncertainty.

There are also several problems such as the absence of capital for entrepreneurship. This is due to the standard of living that is still in the lower middle class and difficult to get loan funds. The absence of knowledge on how to obtain raw materials. This is due to the limited space and access to raw material sources. The absence of production knowledge.This is caused because they have never attended education and/or training to produce and develop production, let alone do a verification. The absence of knowledge about the market. This is due to the lack of knowledge about marketing concepts and strategies.

Based on several problems that emerge in human resources of North Meruya District, UMB carry out this service activity through field surveys, interviews, and direct practice. Based on the results of interviews with several residents, they desperately needed coconut management training to add knowledge and technical skills to obtain coconut management skills.

Related to the identification of the problems that have been submitted, the discussion of the expected problems has done due to provide understanding and knowledge about coconut management as a business of MSMEs, Provide training and technical skills to the community regarding coconut management, as well as to provide a simulation of the coconut management process.

\section{CONCLUSION}

Overall, trainees are dominated by individuals who have a creative spirit. Participants are able to express their ideas and opinions but need time to adjust well in training situations. The thinking patterns of the participants are quite open and flexible. The class atmosphere is quite lively and 'life'. Creative participants and tend to be brave to express their opinions openly, both in group discussions and individually.

The participants stated that the training activities was very interesting, many things were 'new' and learned during the activities. Training materials are very useful in 'delivering' participants to better understand coconut management. This activity can be used as a means of communication, friendship and socialization of Mercu Buana University's Master of Management Postgraduate Program to the community, as well as the realization of the social responsibility of the Higher Education Institution Tri Darma Perguruan Tinggi.

\section{Recommendation}


The duration of the implementation of training activities can be extended, to two days. Within two days of implementing the activity, it is expected that the material and practices related to coconut management can be delivered more optimally.

\section{REFERENCES}

Chandra, G. (2002). Strategi dan program pemasaran. Edisi I, Yogyakarta: Andi Offset.

Fernandez, R. R. (1996). Mutu Terpadu dalam Manajemen Pembelian dan Pemasok. Pustaka Binaman Presindo. Jakarta.

Kartajaya, Hermawan. (2001). Marketing Plus 2000 Siasat Memenangkan Pasar Persaingan Global. Jakarta: PT Gramedia Pustaka Utama.

Kasali, R. (2000). Membidik Pasar Indonesia (Segmenting. Targeting dan Positioning (Jakarta: Gramedia, 2001).

Kotler, P. (1997). Manajemen Pemasaran Analisis, Perencanaan, Implementasi dan Kontrol. Jakarta: Prenhallindo 